\title{
Enantiomer-selective ultraviolet photolysis of temperature-controlled protonated tryptophan on a chiral crown ether in the gas phase
}

\author{
Akimasa Fujihara *, Takashi Sato, and Shigeo Hayakawa \\ Department of Chemistry, Graduate School of Science, Osaka Prefecture University, 1-1 \\ Gakuen-cho, Naka-ku, Sakai, Osaka 599-8531, Japan \\ *Corresponding Author. E-mail: fujihara@c.s.osakafu-u.ac.jp
}

\begin{abstract}
Enantiomer-selective ultraviolet photolysis of temperature-controlled protonated tryptophan $\left(\operatorname{TrpH}^{+}\right)$on the chiral crown ether, (+)-(18-crown-6)-2,3,11,12-tetracarboxylic acid (18C6TA), was examined using a tandem mass spectrometer containing a temperature-variable 22-pole ion trap. The spectra of D-TrpH ${ }_{-}^{+}(+)-18 \mathrm{C} 6 \mathrm{TA}$ at 9-320 K showed that the loss of $\mathrm{NH}_{2} \mathrm{CH}_{2} \mathrm{COOH}$ due to $\mathrm{C}_{\alpha}-\mathrm{C}_{\beta}$ bond cleavage decreased gradually with increasing temperature. The spectrum at room temperature was similar to that of $\mathrm{L}-\mathrm{TrpH}^{+}-(+)-18 \mathrm{C} 6 \mathrm{TA}$, which showed no temperature dependence on photolysis. The chiral-specific photolysis of cold D-TrpH $\mathrm{H}^{+}-(+)-18 \mathrm{C} 6 \mathrm{TA}$ was attributed to the structures involving the chiral-dependent interactions of the $\mathrm{C}_{a}-\mathrm{H}$ group of $\operatorname{TrpH}^{+}$ with the oxygen atoms of $(+)-18 \mathrm{C} 6 \mathrm{TA}$.
\end{abstract}




\section{Graphical abstract}

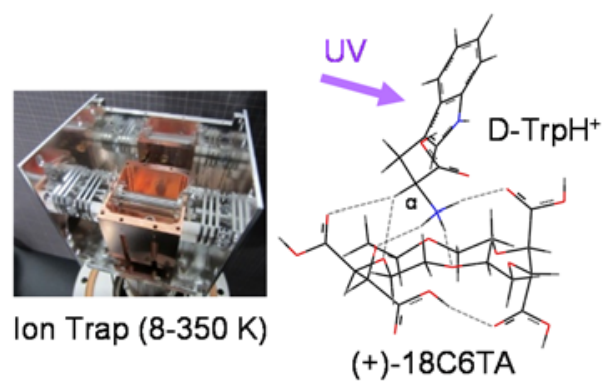

\section{Keywords}

Photolysis, Tryptophan, Enantiomer, Chiral recognition, Homochirality

\section{Highlights}

1) A tandem mass spectrometer for photodissociation spectroscopy of temperature-controlled hydrogen-bonded cluster ions was developed.

2) Enantiomer-specific $\mathrm{C}_{\alpha}-\mathrm{C}_{\beta}$ bond cleavage exhibited a clear dependence on temperature.

3) Enantiomer-selective photolysis of cold amino acids on chiral substances in the gas phase could induce an excess of L-amino acids.

\section{Introduction}

Proteins consist of L-amino acids. The origin of homochirality in biomolecules has been one of the most interesting phenomena in science, and several hypotheses for the origin of homochirality have been proposed [1,2]. An excess of L-amino acids found in the Murchison meteorites indicated an extraterrestrial origin of homochirality [3]. The circular polarization observed in the starformation regions implied that the enantiomer-selective photodestruction with circularly polarized light could induce an enantiomeric enrichment of amino acids in the interstellar space [4,5]. The 
enantiomer selectivity of organic chiral molecules on the surface has been previously reported by several groups [6-8]. Therefore, it is considered that the enantiomer-selective photodestruction of amino acids on chiral substances could play an important role in understanding the origin of homochirality in interstellar molecular clouds.

Chemical processes in interstellar molecular clouds occur at low temperatures over the range of $10-100 \mathrm{~K}$, at low densities over the range of $10^{2}-10^{4} \mathrm{~cm}^{-3}$, and in intense radiation fields. To investigate the enantiomer-selective photodestruction of amino acids on chiral substances, thereby inducing an excess of L-amino acids in interstellar molecular clouds, experimental studies on the photolysis of temperature-controlled gas-phase clusters consisting of amino acid enantiomers and a chiral substance are necessary. Gerlich and coworkers developed a 22-pole radio frequency (RF) ion trap cooled using a refrigeration system, and studied the ion-molecule reactions related to interstellar chemistry [9]. Collisional cooling in a trap is one of the most frequently used methods for controlling the temperature of gas-phase ions. Recently, several groups have developed experimental apparatus using cold ion traps, and investigated the gas-phase cold molecular ions in the field of interstellar and physical chemistry [10].

Tryptophan (Trp) and its derivatives have been used as probes to investigate the structures and reactions of various biomolecules because of their high absorption intensity in the ultraviolet (UV) region and strong fluorescence yields. The photo-induced dissociation (PID) of gas-phase protonated tryptophan $\left(\mathrm{TrpH}^{+}\right)$has been investigated by several groups in order to elucidate the structure and reactivity of amino acids [11-16]. UV excitation at $266 \mathrm{~nm}$ of room-temperature $\mathrm{TrpH}^{+}$, wherein a proton is attached to the amino group, induces hydrogen atom loss because of the mixing of the $\pi \pi^{*}$ state with the dissociative $\pi \sigma^{*}$ state [12]. The $\mathrm{S}_{1}-\mathrm{S}_{0}$ spectra of solvated $\mathrm{TrpH}^{+}$changed drastically with the number of solvent molecules $[17,18]$. This behavior was 
interpreted in terms of a decrease in the interaction between the $\pi \pi^{*}$ and dissociative $\pi \sigma^{*}$ states.

The photodissociation pathways of $\mathrm{TrpH}^{+}$complexed with 18-crown-6 (18C6) at room temperature were reported to be different from those of $\operatorname{TrpH}^{+}$[19]. $18 \mathrm{C} 6$ binds to the $\mathrm{NH}_{3}{ }^{+}$moiety of $\operatorname{TrpH}^{+}$[20], thereby preventing $\mathrm{N}-\mathrm{H}$ bond cleavage, which is an important dissociation channel of $\operatorname{TrpH}^{+}$[14]. The dissociation and electronic structures of $\operatorname{TrpH} H^{+}$are largely affected by their environment.

In this study, we examined the UV photolysis of temperature-controlled $\operatorname{TrpH}^{+}$enantiomers on the chiral crown ether $(+)-(18$-crown-6)-2,3,11,12-tetracarboxylic acid (18C6TA). $(+)-18 \mathrm{C} 6 \mathrm{TA}$, shown in Figure 1, was used as a model for chiral substances. It is a chiral selector for various amino acids in high-performance liquid chromatography (HPLC) with a (+)-18C6TA-linked column [21]. On the basis of these results and theoretical calculations, we discussed the enantiomer-selective photolysis and structures of amino acids on chiral substances.

\section{Experimental}

A tandem mass spectrometer for photodissociation spectroscopy of temperature-controlled gasphase cluster ions was developed. The apparatus consisted of seven differentially evacuated chambers, which contained an electrospray interface, an octopole ion guide, a quadrupole mass filter for mass selection of the precursor ions, a temperature-variable 22-pole ion trap, and a reflectron time-of-flight (TOF) mass spectrometer for mass analysis of fragment ions as shown in Figure 2. Protonated amino acid-crown ether complexes were generated using the spray ionization method and transferred to the gas phase through a metal capillary and skimmer. The ions, guided by an octopole, were deflected by $90^{\circ}$ using an electrostatic quadrupole ion bender into a quadrupole mass filter. The mass-selected ions were decelerated and refocused using a stack of 
five cylindrical electrodes into a temperature-variable 22-pole ion trap $(8-350 \mathrm{~K})$. In the trap, the ions were thermalized by multiple collisions with He buffer gas contained within a copper housing at a well-defined temperature, analogous to a thermal bath [9]. The temperature-controlled ions were extracted from the trap and then irradiated with a photodissociation laser pulse. The fragmented ions were orthogonally accelerated to $2.8 \mathrm{keV}$ using two-stage pulsed electric fields, and then mass analyzed using a reflectron TOF mass spectrometer. The ion signals were detected using dual microchannel plates (F1552-23S, Hamamatsu) and stored in a digital storage oscilloscope (6100A, LeCroy) after being amplified using a wide-band amplifier (BX-31, NF Electronic Instruments). The repetition rate of the experimental cycle was $10 \mathrm{~Hz}$, and the trapping time of the ions was $\sim 80 \mathrm{~ms}$. The fourth harmonic of a Nd:YAG laser (Minilite II, Continuum) was used for the photodissociation light. The typical laser fluence was around $2 \mathrm{~mJ} / \mathrm{cm}^{2}$.

The 22-pole ion trap consisted of a pair of RF electrodes with 11 rods each. The rods had a diameter of $1 \mathrm{~mm}$ and length of $38 \mathrm{~mm}$, and they were equally spaced with an inscribed radius of $5 \mathrm{~mm}$. To guarantee good heat conduction, the trap assembly was constructed from as few parts as possible [22]. The two RF stainless steel electrodes and copper housing were made in one piece using a wire-electrical discharge machine and machining center, and chemically polished. The trap assembly was mounted onto the second stage of a cryogenic refrigerator (CH-204SB, Sumitomo). To control the trap temperature over the range of $8-350 \mathrm{~K}$, a $50 \mathrm{~W}$ heater cartridge (HTR-50, LakeShore) and two silicon diode temperature sensors (DT-670B-CU, LakeShore) were attached to the copper housing of the trap. The copper housing was enclosed within an aluminum radiation shield, which was in thermal contact with the first stage at $50 \mathrm{~K}$. All electrical connections and a gas line were precooled to this temperature. In the axial direction, the ions were trapped by the applied dc voltage at the cylindrical entrance and exit electrodes. The typical difference in the 
electric potentials between the electrodes and center potential of the RF was $1 \mathrm{~V}$. An RF amplitude (zero-to-peak) of $100 \mathrm{~V}$ was applied to the rods of the trap at a fixed frequency of $4 \mathrm{MHz}$.

The samples of L-Trp, D-Trp, (+)-18C6TA, and 18C6 used in this study were commercially available from Sigma-Aldrich. The purities of the D-Trp, (+)-18C6TA, and 18C6 were 98, 97, and $99 \%$, respectively. A solution containing $200 \mu \mathrm{M}$ of amino acid and $400 \mu \mathrm{M}$ of crown ether in a mixture of water and methanol (50/50) was used.

The geometry optimization was carried out using density functional theory (DFT) calculations at the B3LYP/6-31+G(d) level using GAUSSIAN 09 [23]. In this study, we performed optimizations for each species starting from many initial configurations according to the conformers in the reports for similar systems [24-26]. The geometries of the complexes were optimized using the energy gradient technique at the B3LYP/6-31+G(d) level. The vibrational analyses were carried out for each optimized structure to confirm the minima on the potential energy surfaces. The zero-point vibrational correction (ZPC) was included in the calculated binding energies using scaled harmonic frequencies, wherein the scale factor 0.956 was used.

\section{Results and discussion}

3.1. UV photolysis of cold $\mathrm{TrpH}^{+}$enantiomers on a chiral crown ether

Figures $3 \mathrm{a}$ and $\mathrm{b}$ show the photodissociation mass spectra of $\mathrm{D}-\mathrm{TrpH}^{+}-(+)-18 \mathrm{C} 6 \mathrm{TA}$ and L$\mathrm{TrpH}^{+}-(+)-18 \mathrm{C} 6 \mathrm{TA}(\mathrm{m} / \mathrm{z} 645)$, respectively, at $9 \mathrm{~K}$. The excitation wavelength was $266 \mathrm{~nm}$, which excited the indole $\pi$ electron of tryptophan to the $\pi \pi^{*}$ excited state [12]. The fragment ions $\mathrm{m} / \mathrm{z}$ 205 and 188 were observed in the spectra, which corresponded to free $\operatorname{TrpH}^{+}$formed via the loss 
of the chiral crown ether and the $\mathrm{NH}_{3}$-eliminated product of the free $\mathrm{TrpH}^{+}$, respectively. As for these dissociation channels, a difference between the D- and L-enantiomers was not detected. In the photodissociation of the cold $\mathrm{TrpH}^{+}$enantiomers, which remained associated with $(+)-18 \mathrm{C} 6 \mathrm{TA}$, the fragment ion $\mathrm{m} / \mathrm{z} 601$ was the $\mathrm{CO}_{2}$-eliminated product, whereas the loss of $\mathrm{NH}_{3}$ from the $\operatorname{TrpH}^{+}$ on the chiral crown ether was not observed. The fragment ion $\mathrm{m} / \mathrm{z} 570$ corresponding to the loss of $\mathrm{NH}_{2} \mathrm{CH}_{2} \mathrm{COOH}$ via $\mathrm{C}_{\alpha}-\mathrm{C}_{\beta}$ bond cleavage was observed in the spectrum of D-TrpH $\mathrm{H}^{+}(+)$18C6TA at $9 \mathrm{~K}$, whereas a small amount of $\mathrm{NH}_{2} \mathrm{CH}_{2} \mathrm{COOH}$-eliminated product was observed in the spectrum of L-TrpH ${ }^{+}-(+)-18 \mathrm{C} 6 \mathrm{TA}$, as shown in Figure 3. It was difficult to discuss the minor peaks in detail owing to the impurities in the samples of small chiral molecules. However, the branching ratio of the $\mathrm{NH}_{2} \mathrm{CH}_{2} \mathrm{COOH}$-eliminated product was clearly different between the D-and L-enantiomers. It was understood that the loss of $\mathrm{NH}_{2} \mathrm{CH}_{2} \mathrm{COOH}$ via $\mathrm{C}_{\alpha}-\mathrm{C}_{\beta}$ bond cleavage, observed in the spectrum of the cold D-TrpH $\mathrm{H}^{+}(+)-18 \mathrm{C} 6 \mathrm{TA}$, was correlated with the chiraldependent interaction of amino acid enantiomers with the chiral crown ether. This was because the L-enantiomer was usually eluted prior to the D-enantiomer in the separation of amino acid enantiomers using HPLC with a (+)-18C6TA-linked column [24,25].

To confirm the chiral-specific photolysis by comparing it with the photolysis of the enantiomers on an achiral crown ether, photodissociation experiments of cold $\operatorname{TrpH}^{+}$enantiomers on $18 \mathrm{C} 6$ were performed. $18 \mathrm{C} 6$ is a polyether ring, which lacks four carboxyl groups in $(+)-18 \mathrm{C} 6 \mathrm{TA}$. Figure 4 shows the photodissociation mass spectra of D-TrpH $\mathrm{H}^{+}-18 \mathrm{C} 6$ and $\mathrm{L}-\operatorname{TrpH}^{+}-18 \mathrm{C} 6(\mathrm{~m} / \mathrm{z} 469)$ at $9 \mathrm{~K}$. The fragment ions observed were $\mathrm{m} / \mathrm{z} 425,205$, and 188 , which corresponded to the loss of $\mathrm{CO}_{2}$, free $\operatorname{TrpH} H^{+}$, and loss of $\mathrm{NH}_{3}$ from the free $\mathrm{TrpH}^{+}$, respectively. The peaks marked with asterisks were assigned to the $\mathrm{CO}_{2}$-eliminated product in the field-free region of the reflectron TOF mass spectrometer. The spectra showed no difference between the D- and L-enantiomers, and the 
product ions were similar to those of $\mathrm{L}_{-} \mathrm{TrpH}^{+}-(+)-18 \mathrm{C} 6 \mathrm{TA}$ shown in Figure $3 \mathrm{~b}$. The loss of $\mathrm{NH}_{2} \mathrm{CH}_{2} \mathrm{COOH}$ was not observed in the spectra of D-TrpH $\mathrm{H}^{+}-18 \mathrm{C} 6, \mathrm{~L}-\operatorname{TrpH}^{+}-18 \mathrm{C} 6$, and $\mathrm{L}_{-} \operatorname{TrpH}^{+}$$(+)-18 \mathrm{C} 6 \mathrm{TA}$ at $9 \mathrm{~K}$; the loss of $\mathrm{NH}_{2} \mathrm{CH}_{2} \mathrm{COOH}$ via $\mathrm{C}_{\alpha}-\mathrm{C}_{\beta}$ bond cleavage was the main photodissociation pathway only in cold D-TrpH $\mathrm{H}^{+}-(+)-18 \mathrm{C} 6 \mathrm{TA}$, thereby indicating chiral-specific photolysis.

\subsection{Chiral-specific interactions}

We calculated the structures of 1:1 complexes of the L- and D-enantiomers and crown ethers using the DFT method. Figure 5 shows optimized lowest-energy structures and relative binding energies with ZPC of D-TrpH ${ }^{+}-(+)-18 \mathrm{C} 6 \mathrm{TA}$ and $\mathrm{L}_{-} \operatorname{TrpH}^{+}-(+)-18 \mathrm{C} 6 \mathrm{TA}$ at the B3LYP/6-31+G(d) level. The optimized structure of D-TrpH $\mathrm{H}^{+}-18 \mathrm{C} 6$ is also shown for comparison, which was based on that predicted in infrared multiphoton dissociation (IRMPD) spectra of protonated amino acidcrown ether complexes [20]. The dotted lines represented hydrogen bonds. The structure and atomic numbering of $(+)$-18C6TA used in this study is shown in Figure 1. In all the complexes of $\operatorname{TrpH}^{+}$enantiomers and the chiral crown ether, $(+)$-18C6TA took up an asymmetric bowl-like conformation formed by the intramolecular hydrogen bonds involving the carboxyl groups located under the plane of the ring. The indole ring and carboxyl group of $\operatorname{TrpH} H^{+}$determined the spatial location of each enantiomer with respect to $(+)$-18C6TA. In the D1 and $\mathbf{D 2}$ structures of D-TrpH ${ }^{+}$$(+)$-18C6TA, the $\mathrm{NH}_{3}{ }^{+}$group formed hydrogen bonds with the three oxygen atoms of $(+)$18C6TA: O20 atom of the carboxyl group, and $\mathrm{O} 7$ and $\mathrm{O} 13$ atoms of the polyether ring. However, O1, O7, and $\mathrm{O} 13$ atoms of the polyether ring participated in the hydrogen bonds in the $\mathbf{L} \mathbf{1}$ structure of L-TrpH ${ }^{+}-(+)-18 \mathrm{C} 6 \mathrm{TA}$. For $\mathrm{TrpH}^{+}-18 \mathrm{C} 6$, shown in Figure 5c, the $\mathrm{NH}_{3}{ }^{+}$group was bound to the three oxygen atoms of the polyether ring, as in the $\mathbf{L 1}$ structure of $\mathrm{L}-\mathrm{TrpH}^{+}-(+)-18 \mathrm{C} 6 \mathrm{TA}$. In addition to these hydrogen bonds of the $\mathrm{NH}_{3}{ }^{+}$group with the oxygen atoms of $(+)-18 \mathrm{C} 6 \mathrm{TA}$, the 
$\mathrm{C}_{\alpha}-\mathrm{H}$ group interacted with the oxygen atoms of $(+)-18 \mathrm{C} 6 \mathrm{TA}$. In the D1 and D2 structures, the $\mathrm{C}_{\alpha}-\mathrm{H}$ group of $\mathrm{D}-\mathrm{TrpH}^{+}$interacted with the $\mathrm{O} 10$ atom of the polyether ring and $\mathrm{O} 26$ atom of the carboxyl group of (+)-18C6TA.

The chiral-specific interactions between the $\mathrm{C}_{\alpha}-\mathrm{H}$ group of amino acids and oxygen atoms of $(+)$-18C6TA have been reported using NMR and X-ray analyses, and these pertain to the chiral separation using HPLC with a (+)-18C6TA-linked column [24-26]. These reported interactions were consistent with our calculated results. The ${ }^{1} \mathrm{H}$ NMR spectra of 1:1 complexes of L- and Damino acids and (+)-18C6TA in solution showed that the chemical shift of the $\mathrm{C}_{\alpha}$ proton towards the lower-field side in the D-amino acid with (+)-18C6TA was larger than that in the L-amino acid [24]. These results indicated that the $\mathrm{C}_{\alpha}-\mathrm{H}$ group participated in the hydrogen bond with the acceptor atom of $(+)-18 \mathrm{C} 6 \mathrm{TA}$, and that the interaction of the D-amino acid with $(+)-18 \mathrm{C} 6 \mathrm{TA}$ was stronger than that of the L-amino acid. The lowest-energy structure D1 of D-TrpH ${ }^{+}-(+)-18 \mathrm{C} 6 \mathrm{TA}$ and $\mathbf{~} \mathbf{1}$ of L-TrpH $\mathrm{H}^{+}-(+)-18 \mathrm{C} 6 \mathrm{TA}$ were consistent with the structures reported by Nagata et al. using X-ray crystallography, NMR measurement, and molecular orbital calculation [24-26]. Therefore, the loss of $\mathrm{NH}_{2} \mathrm{CH}_{2} \mathrm{COOH}$ via $\mathrm{C}_{\alpha}-\mathrm{C}_{\beta}$ bond cleavage observed only in the spectrum of cold D$\operatorname{TrpH}^{+}-(+)-18 \mathrm{C} 6 \mathrm{TA}$ was assigned to the chiral-specific photolysis of structures such as D1 and D2. In the photodissociation of the cold $\mathrm{TrpH}^{+}$enantiomers, which remained associated with (+)18C6TA, the loss of $\mathrm{CO}_{2}$ was observed, whereas the loss of $\mathrm{NH}_{3}$ from the $\mathrm{TrpH}^{+}$on the chiral crown ether was not observed, as shown in Figure 3. The loss of $\mathrm{CO}_{2}$ from amino acids isolated in a cold matrix has been previously reported to be the dominant photoproduct under UV irradiation, wherein the amino acids were non-zwitterionic with $\mathrm{NH}_{2}$ and $\mathrm{COOH}$ groups [27]. In PID and collision-induced dissociation (CID) experiments of free $\mathrm{TrpH}^{+}$at room temperature, the losses of $\mathrm{NH}_{3}$ and $\left(\mathrm{H}_{2} \mathrm{O}+\mathrm{CO}\right)$ have been observed [11-16,28], whereas the $\mathrm{CO}_{2}$-eliminated product was 
not formed. The losses of $\mathrm{NH}_{3}$ and $\left(\mathrm{H}_{2} \mathrm{O}+\mathrm{CO}\right)$ from $\mathrm{TrpH}^{+}$have been proposed to occur via the intramolecular proton transfer from the $\mathrm{NH}_{3}{ }^{+}$group $[14,28]$. In the photodissociation of cold $\mathrm{TrpH}^{+}$, which remained associated with $(+)-18 \mathrm{C} 6 \mathrm{TA}$, dissociations induced by the proton transfer from the $\mathrm{NH}_{3}{ }^{+}$group were suppressed due to the hydrogen bonds of the $\mathrm{NH}_{3}{ }^{+}$group with the crown ether. The loss of $\mathrm{NH}_{2} \mathrm{CH}_{2} \mathrm{COOH}$ via $\mathrm{C}_{\alpha}-\mathrm{C}_{\beta}$ bond cleavage was reported in the PID experiments of free $\operatorname{TrpH}^{+}$[15], wherein a mechanism based on the photo-induced electron transfer from the indole ring to the carboxyl group, followed by proton transfer from the $\mathrm{NH}_{3}{ }^{+}$group to the negatively charged carboxyl group was suggested. As for $\mathrm{TrpH}^{+}$enantiomer-crown ether complexes, the $\mathrm{C}_{a}-\mathrm{C}_{\beta}$ bond cleavage channel proceeded only in cold D-TrpH ${ }^{+}-(+)-18 \mathrm{C} 6 \mathrm{TA}$ as the chiral-specific photolysis. In the D1 and D2 structures of D-TrpH $\mathrm{H}^{+}(+)-18 \mathrm{C} 6 \mathrm{TA}$, one of the hydrogen atoms of the $\mathrm{NH}_{3}{ }^{+}$group was out of the polyether ring and formed hydrogen bond with the carboxyl group of (+)-18C6TA, due to the strong interactions of the $\mathrm{C}_{\alpha}-\mathrm{H}$ group of $\mathrm{TrpH}^{+}$with (+)-18C6TA. The hydrogen atom of the $\mathrm{NH}_{3}{ }^{+}$group, which was out of the polyether ring, could play an important role in the loss of $\mathrm{NH}_{2} \mathrm{CH}_{2} \mathrm{COOH}$ via $\mathrm{C}_{\alpha}-\mathrm{C}_{\beta}$ bond cleavage. The chiral-specific $\mathrm{C}_{\alpha}-\mathrm{C}_{\beta}$ bond cleavage was considered to occur through the photo-induced electron transfer from the indole ring followed by proton transfer from the $\mathrm{NH}_{3}{ }^{+}$group to $\mathrm{COOH}$ group.

\subsection{Temperature effects}

To examine the temperature effects on the photolysis and structures, the photodissociation mass spectra of the $\mathrm{TrpH}^{+}$enantiomers on (+)-18C6TA were measured over the temperature range of 9-320 K. Figure 6 shows the photodissociation mass spectra of D-TrpH ${ }^{+}-(+)-18 \mathrm{C} 6 \mathrm{TA}$ and L$\mathrm{TrpH}^{+}-(+)-18 \mathrm{C} 6 \mathrm{TA}$ at 9-300 K. The spectra were normalized at the peak of the precursor ion. In the spectra of D-TrpH $\mathrm{H}^{+}(+)-18 \mathrm{C} 6 \mathrm{TA}$, the $\mathrm{NH}_{2} \mathrm{CH}_{2} \mathrm{COOH}$-eliminated product decreased gradually with increasing temperature, whereas the spectra of $\mathrm{L}-\mathrm{TrpH}^{+}-(+)-18 \mathrm{C} 6 \mathrm{TA}$ showed no temperature 
dependence on the photolysis, wherein the main photodissociation pathway was the loss of $\mathrm{CO}_{2}$. The spectrum of D-enantiomer at room temperature was similar to that of L-enantiomer. During the structural optimizations, we found isomer D3 of D-TrpH ${ }^{+}-(+)-18 \mathrm{C} 6 \mathrm{TA}$, shown in Figure 5. Isomer D3 was higher in energy by $4.74 \mathrm{~kJ} / \mathrm{mol}$ compared to the lowest-energy structure D1 of D$\mathrm{TrpH}^{+}-(+)-18 \mathrm{C} 6 \mathrm{TA}$. In the $\mathbf{D 3}$ structure of D-TrpH ${ }^{+}-(+)-18 \mathrm{C} 6 \mathrm{TA}$ and $\mathbf{L 1}$ structure of L-TrpH ${ }^{+}-$ (+)-18C6TA, the $\mathrm{NH}_{3}{ }^{+}$group formed hydrogen bonds with $\mathrm{O} 1, \mathrm{O} 7$, and $\mathrm{O} 13$ atoms of the polyether ring, and the $\mathrm{C}_{\alpha}-\mathrm{H}$ group interacted with $\mathrm{O} 20$ atom of the carboxyl group of (+)-18C6TA. The D3 and $\mathbf{L 1}$ structures differed in the interactions from the D1 and D2 structures. In the D3 structure of D-TrpH ${ }^{+}-(+)-18 \mathrm{C} 6 \mathrm{TA}$, L1 structure of $\mathrm{L}-T r p H^{+}-(+)-18 \mathrm{C} 6 \mathrm{TA}$, and D-TrpH ${ }^{+}-18 \mathrm{C} 6$, shown in Figure 5, three hydrogen atoms of the $\mathrm{NH}_{3}{ }^{+}$group formed hydrogen bonds with the oxygen atoms of the polyether ring. Therefore, the product ions of $\mathrm{D}-\mathrm{TrpH}^{+}-(+)-18 \mathrm{C} 6 \mathrm{TA}$ at room temperature were assigned to the chiral-independent photolysis of structures such as D3, wherein the interactions were similar to those in the $\mathrm{L}-\mathrm{TrpH}^{+}-(+)-18 \mathrm{C} 6 \mathrm{TA}$. At room temperature, an entropic effects could contribute a population of the structures.

The yields of the loss of $\mathrm{NH}_{2} \mathrm{CH}_{2} \mathrm{COOH}$ from D-TrpH $\mathrm{H}^{+}(+)-18 \mathrm{C} 6 \mathrm{TA}$ and $\mathrm{L}-\mathrm{TrpH} \mathrm{H}^{+}-(+)-$ $18 \mathrm{C} 6 \mathrm{TA}$, derived from (product ion intensity/precursor ion intensity) $\times 100$ at $9-320 \mathrm{~K}$, are shown in Figure 7. The loss of $\mathrm{NH}_{2} \mathrm{CH}_{2} \mathrm{COOH}$ from D-TrpH $\mathrm{H}^{+}(+)-18 \mathrm{C} 6 \mathrm{TA}$ gradually decreased with increasing temperature, whereas that from the L-enantiomer showed no temperature dependence. As for the temperature dependence of the interaction of the amino acid enantiomers with $(+)-$ 18C6TA, the chemical shifts of the $\mathrm{C}_{\alpha}$ proton of the amino acid enantiomers complexed with $(+)-$ 18C6TA in solution were measured over the range of 273-323 K [24]. The chemical shift of the D-enantiomer decreased with increasing temperature, although that of the L-enantiomer shows little change. Furthermore, it was found that HPLC using a (+)-18C6TA-linked column was more 
effective in separating the enantiomers at low temperature [21]. The temperature dependencies reported for the chemical shifts of the $\mathrm{C}_{\alpha}$ proton and HPLC confirmed that the loss of $\mathrm{NH}_{2} \mathrm{CH}_{2} \mathrm{COOH}$ via $\mathrm{C}_{\alpha}-\mathrm{C}_{\beta}$ bond cleavage of D-TrpH ${ }^{+}-(+)-18 \mathrm{C} 6 \mathrm{TA}$ observed at lower temperature was attributable to the chiral-dependent interaction of the $\mathrm{C}_{a}-\mathrm{H}$ group of $\mathrm{TrpH}^{+}$with $(+)-18 \mathrm{C} 6 \mathrm{TA}$ formed in the D1 and D2 structures.

\section{Conclusion}

Enantiomer-selective UV photolysis of temperature-controlled $\operatorname{TrpH}^{+}$on the chiral crown ether $(+)$-18C6TA was examined using a tandem mass spectrometer containing a temperature-variable 22-pole ion trap. In the spectra of D-TrpH ${ }^{+}-(+)-18 \mathrm{C} 6 \mathrm{TA}$ at 9-320 K, the loss of $\mathrm{NH}_{2} \mathrm{CH}_{2} \mathrm{COOH}$ via $\mathrm{C}_{\alpha}-\mathrm{C}_{\beta}$ bond cleavage decreased gradually with increasing temperature, whereas the spectra of L-TrpH ${ }^{+}-(+)-18 \mathrm{C} 6 \mathrm{TA}$ showed no temperature dependence on photolysis. The spectrum of the Denantiomer at room temperature was similar to that of the L-enantiomer, wherein the main photodissociation pathway was the loss of $\mathrm{CO}_{2}$. The loss of $\mathrm{NH}_{2} \mathrm{CH}_{2} \mathrm{COOH}$ observed only in the spectra of cold D-TrpH $\mathrm{H}^{+}(+)-18 \mathrm{C} 6 \mathrm{TA}$ was attributed to the chiral-specific photolysis of the structures involving the chiral-dependent interactions of the $\mathrm{C}_{\alpha}-\mathrm{H}$ group of $\mathrm{TrpH}^{+}$with the oxygen atoms of $(+)-18 \mathrm{C} 6 \mathrm{TA}$. The calculations of the optimized structures indicated that the product ions of $\mathrm{D}-\mathrm{TrpH}^{+}-(+)-18 \mathrm{C} 6 \mathrm{TA}$ at room temperature were attributable to the chiral-independent photolysis of the structures, wherein the three hydrogen atoms of the $\mathrm{NH}_{3}{ }^{+}$group formed hydrogen bonds with the polyether ring, as with the structure of $\mathrm{L}-\operatorname{TrpH}^{+}-(+)-18 \mathrm{C} 6 \mathrm{TA}$.

\section{Acknowledgment}


This work was supported by JSPS KAKENHI Grant Number 23750021, JST A-STEP Grant Number AS231Z03102B, and Grants from The New Technology Development Foundation, The Sumitomo Foundation, Shimadzu Science Foundation, The Iwatani Naoji Foundation, and The Kurata Memorial Hitachi Science and Technology Foundation.

\section{References}

[1] W.A. Bonner, Orig. Life Evol. Biosphere 21 (1991) 59.

[2] K. Ruiz-Mirazo, C. Briones, A. Escosura, Chem. Rev. 114 (2014) 285.

[3] J.R. Cronin, S. Pizzarello, Science 275 (1997) 951.

[4] J. Bailey, A. Chrysostomou, J.H.Hough, T.M. Gledhill, A. McCall, S. Clark, F. Ménard, M. Tamura, Science 281 (1998) 672.

[5] C. Meinert, P.d. Marcellus, L.L.S. d'Hendecourt, L. Nahon, N.C. Jones, S.V. Hoffmann, J. H. Bredehöft, U.J. Meierhenrich, Phys. Life Rev. 8 (2011) 307.

[6] K. Soai, S. Osanai, K. Kadowaki, S. Yonekubo, T. Shibata, I. Sato, J. Am. Chem. Soc. 121 (1999) 11235.

[7] R.M. Hazen, T.R. Filley, G.A. Goodfriend, Proc. Natl. Acad. Sci. 98 (2001) 5487.

[8] C.A. Orme, A. Noy, A. Wierzbicki, M.T. McBride, M. Grantham, H.H. Teng, P.M. Dove, J.J. DeYoreo, Nature 411 (2001) 775.

[9] D. Gerlich, Phys. Scripta. T59 (1995) 256.

[10] D. Gerlich, in: I.W.M. Smith (Ed.), Low Temperatures and Cold Molecules, Imperial College Press, London, 2008, p. 295.

[11] D. Nolting, C. Marian, R. Weinkauf, Phys. Chem. Chem. Phys. 6 (2004) 2633. 
[12] H. Kang, C. Jouvet, C. Dedocder-Lardeux, S. Martrenchard, G. Grégoire, C. Desfrançois, J.P. Schermann, M. Barat, J.A. Fayeton, Phys. Chem. Chem. Phys. 7 (2005) 394.

[13] F. O. Talbot, T. Tabarin, R. Antoine, M. Broyer, P.J. Dugourd, Chem. Phys. 122 (2005) 074310 .

[14] V. Lepére, B. Lucas, M. Barat, J.A. Fayeton, V.J. Picard, C. Jouvet, P. Carcabal, I. Nielsen, C. Dedonder-Lardeux. G. Grégoire, A. Fujii, J. Chem. Phys. 127 (2007) 134313.

[15] B. Lucas, M. Barat, J.A. Fayeton, M. Perot, C. Jouvet, G. Grégoire, S.B. Nielsen, J. Chem. Phys. 128 (2008) 164302.

[16] A. Fujihara, H. Matsumoto, Y. Shibata, H. Ishikawa, K. Fuke, J. Phys. Chem. A 112 (2008) 1457.

[17] A. Fujihara, N. Noguchi, Y. Yamada, H. Ishikawa, K. Fuke, J. Phys. Chem. A 113 (2009) 8169.

[18] S.R. Mercier, O.V. Boyarkin, A. Kamariotis, M. Guglielmi, I. Tavernelli, M. Cascella, U. Rothlisberger, T.R. Rizzo, J. Am. Chem. Soc. 128 (2006) 16938.

[19] U. Kadhane, J.U. Andersen, A. Ehlerding, P. Hvelplund, M.-B.S. Kirketerp, M.K. Lykkegaard, S. B. Nielsen, S. Panja, J.A. Wyer, H. Zettergren, J. Chem. Phys. 129 (2008) 184304. [20] C.N. Stedwell, J.F. Galindo, K. Gulyuz, A.E. Roitberg, N.C. Polfer, J. Phys. Chem. A 117 (2013) 1181.

[21] M.H. Hyun, J.S. Jin, H.J. Koo, W. Lee, J. Chromatogr. A 837 (1999) 75.

[22] O. Asvany, F. Bielau, D. Moratschke, J. Krause, S. Schlemmer, Rev. Sci. Instrum. 81 (2010) 076102.

[23] M.J. Frisch et al., Gaussian 09, Revision A.1, Gaussian, Inc., Wallingford, CT, 2009. 
[24] H. Nagata, Y. Machida, H. Nishi, M. Kamigauchi, K. Minoura, T. Ishida, Bull. Chem. Soc. Jpn. 82 (2009) 219.

[25] H. Nagata, H. Nishi, M. Kamigauchi, T. Ishida, Org. Biomol. Chem. 2 (2004) 3470.

[26] H. Nagata, H. Nishi, M. Kamigauchi, T. Ishida, Chirality 20 (2008) 820.

[27] P. Ehrenfreund, M.P. Bernstein, J.P. Dworkin, S.A. Sandford, L.J. Allamandola, Astrophys. J. 550 (2001) L95.

[28] H. Lioe, R.A.J. O'Hair, G.E. Reid, J. Am. Soc. Mass Spectrom. 15 (2004) 65.

\section{Figure Captions}

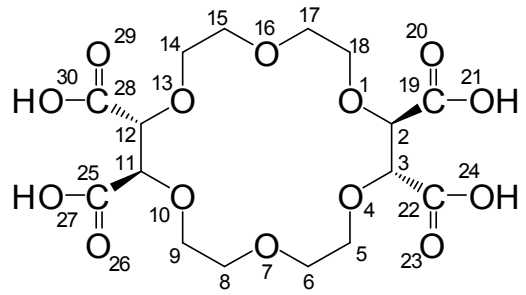

Figure 1. Structure and atomic numbering of $(+)-18 \mathrm{C} 6 \mathrm{TA}$ used in this study.

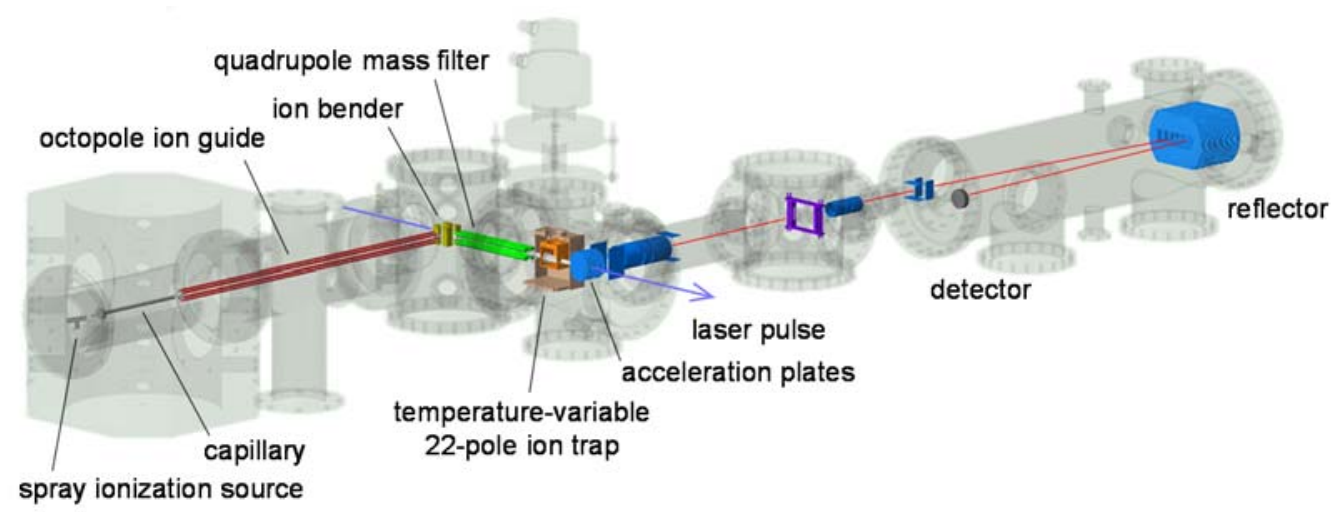


Figure 2. Schematic of experimental apparatus.

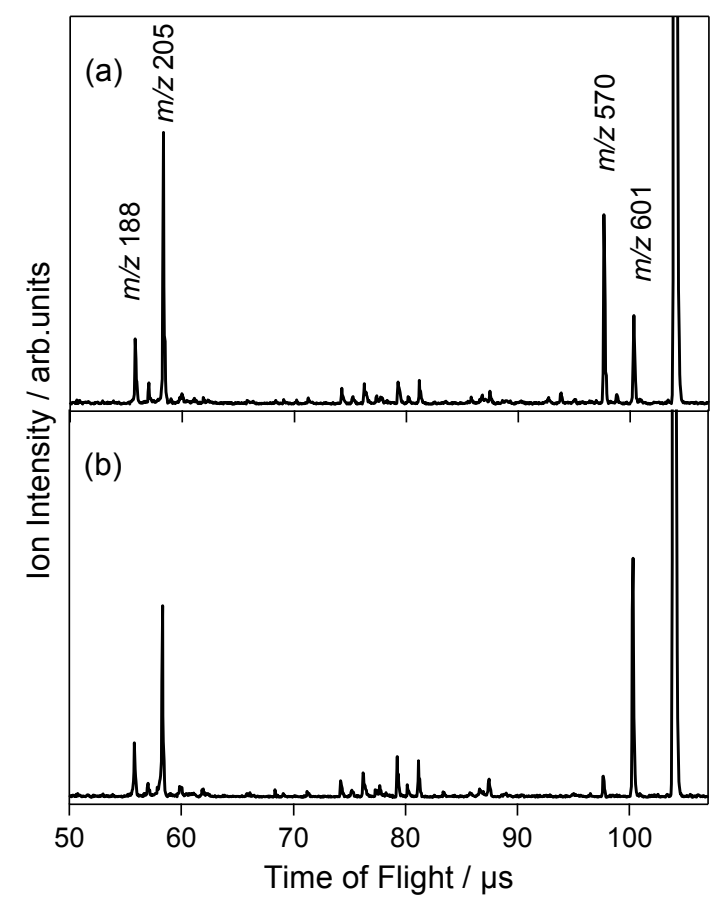

Figure 3. Photodissociation mass spectra of (a) D-TrpH ${ }^{+}-(+)-18 \mathrm{C} 6 \mathrm{TA}$ and (b) $\mathrm{L}-\mathrm{TrpH}^{+}-(+)-$ 18C6TA $(\mathrm{m} / \mathrm{z} 645)$ at $9 \mathrm{~K}$. Excitation wavelength is $266 \mathrm{~nm}$. The spectra are normalized at the peak of the precursor ion. 


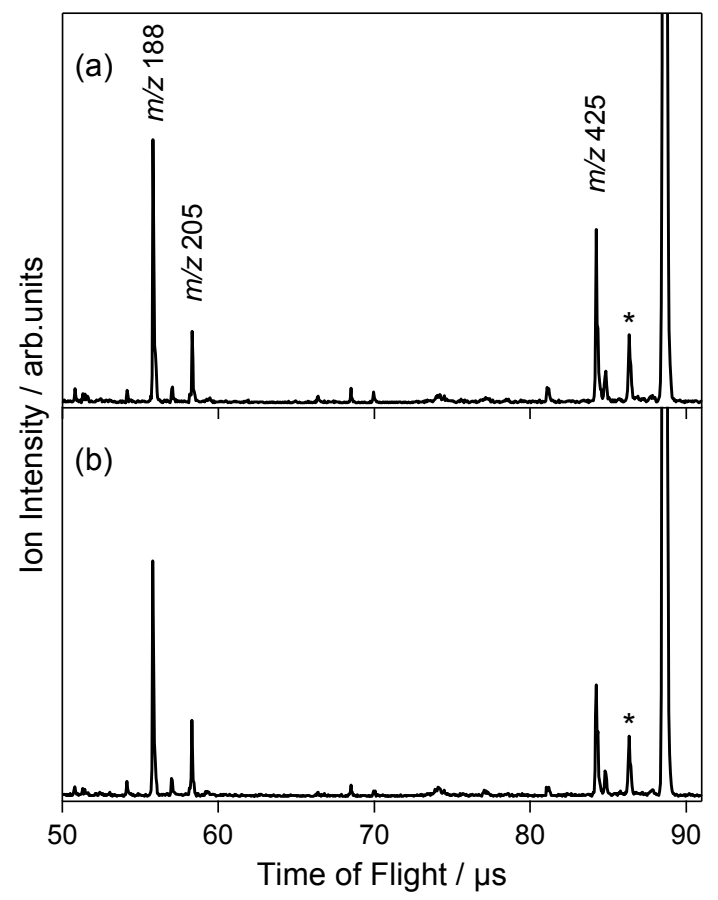

Figure 4. Photodissociation mass spectra of (a) D-TrpH ${ }^{+}-18 \mathrm{C} 6$ and (b) L-TrpH $-18 \mathrm{C} 6$ ( $\left.\mathrm{m} / \mathrm{z} 469\right)$ at $9 \mathrm{~K}$. Excitation wavelength is $266 \mathrm{~nm}$. The spectra are normalized at the peak of the precursor ion. The peaks marked with asterisks are assigned to the $\mathrm{CO}_{2}$-eliminated product in the field-free region of the reflectron TOF mass spectrometer. 
(a) D-TrpH ${ }^{+}(+)-18 \mathrm{C} 6 \mathrm{TA}$
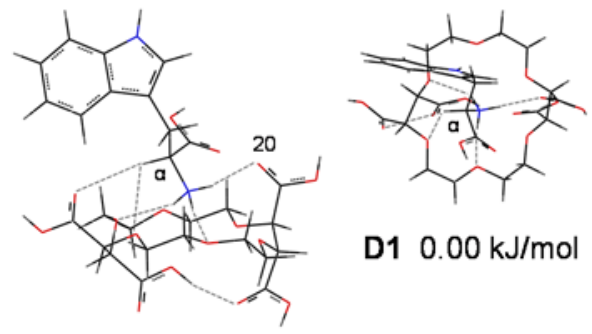

D1 $0.00 \mathrm{~kJ} / \mathrm{mol}$
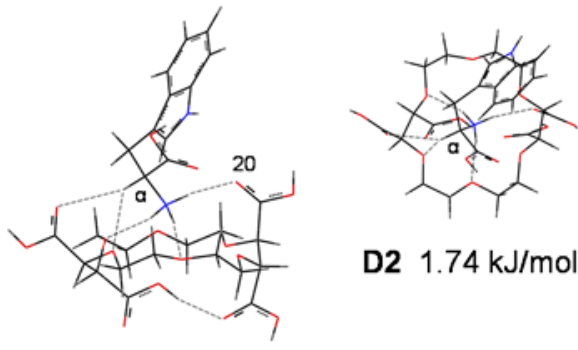

D2 $1.74 \mathrm{~kJ} / \mathrm{mol}$
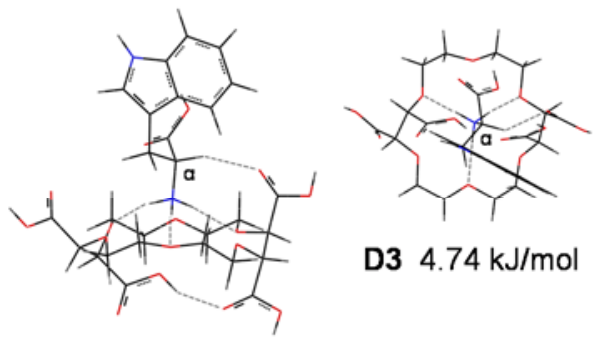

D3 $4.74 \mathrm{~kJ} / \mathrm{mol}$

(b) L-TrpH ${ }^{+}-(+)-18 \mathrm{C} 6 \mathrm{TA}$
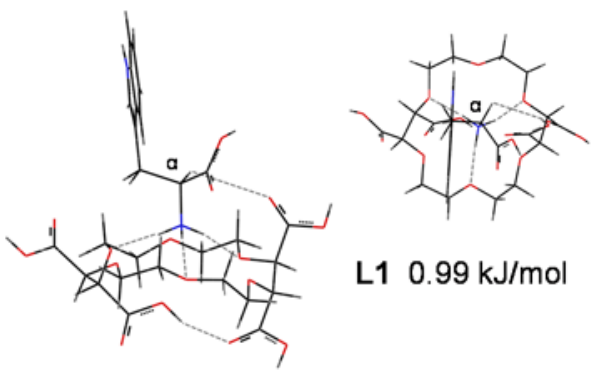

\section{L1 $0.99 \mathrm{~kJ} / \mathrm{mol}$}

(c) D-TrpH+'-18C6
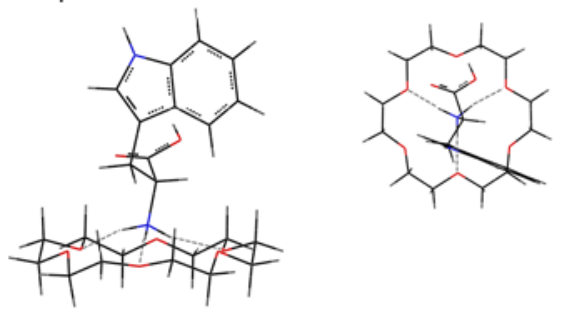

Figure 5. Optimized structures of (a) D-TrpH ${ }^{+}-(+)-18 \mathrm{C} 6 \mathrm{TA}$, (b) L-TrpH ${ }^{+}-(+)-18 \mathrm{C} 6 \mathrm{TA}$, and (c) D-TrpH $H^{+}-18 C 6$ at B3LYP/6-31+G(d) level. Relative binding energies with ZPC are given under each structure. The dotted lines represent either hydrogen bonds or electrostatic interaction. 


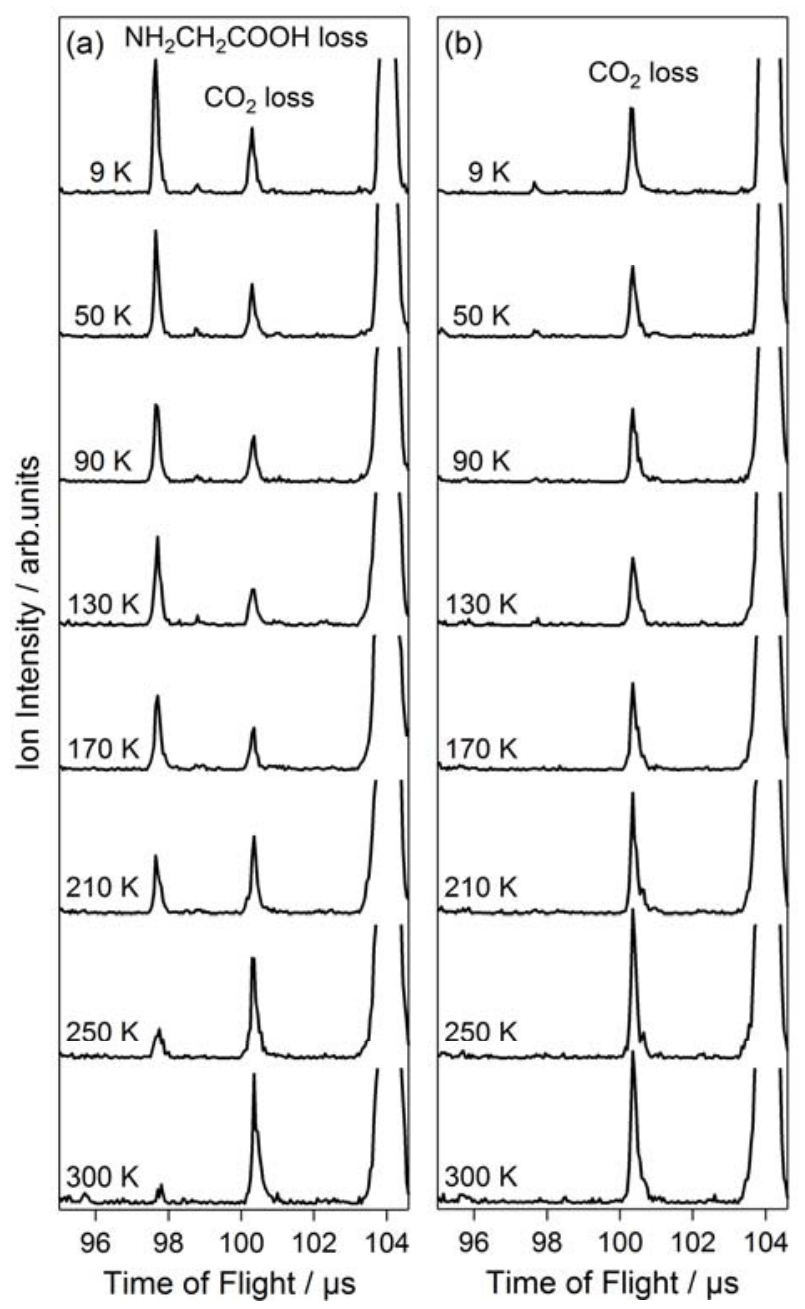

Figure 6. Photodissociation mass spectra of (a) D-TrpH ${ }^{+}-(+)-18 \mathrm{C} 6 \mathrm{TA}$ and (b) $\mathrm{L}-\mathrm{TrpH}^{+}-(+)$18C6TA at 9-300 K. Excitation wavelength is $266 \mathrm{~nm}$. The spectra are normalized at the peak of the precursor ion. 


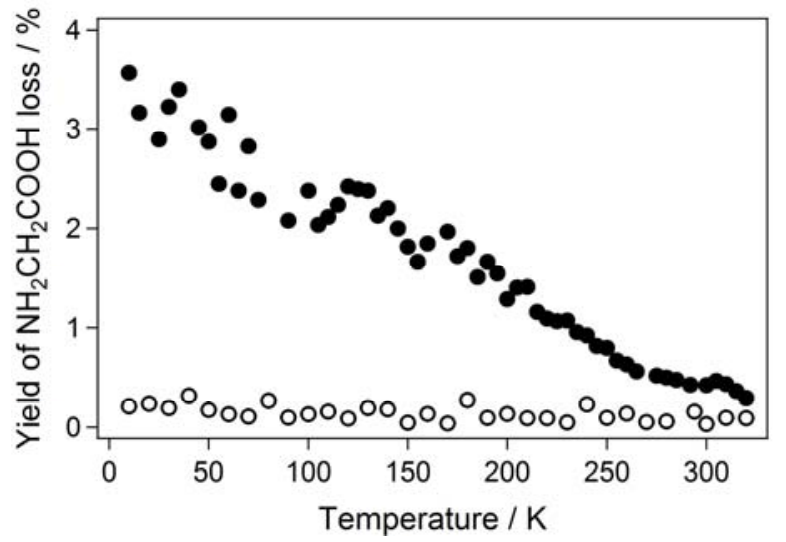

Figure 7. Temperature dependence of the loss of $\mathrm{NH}_{2} \mathrm{CH}_{2} \mathrm{COOH}$ via $\mathrm{C}_{\alpha}-\mathrm{C}_{\beta}$ bond cleavage of D$\operatorname{TrpH}^{+}-(+)-18 \mathrm{C} 6 \mathrm{TA}(\bullet)$ and $\mathrm{L}-\operatorname{TrpH}^{+}-(+)-18 \mathrm{C} 6 \mathrm{TA}(\circ)$. Excitation wavelength is $266 \mathrm{~nm}$. 